NISTIR 6943

\title{
Program Design and Firm Success in the Advanced Technology Program: Project Structure and Innovation Outcomes
}

Michael R. Darby University of California, Los Angeles Los Angeles, CA 90095 National Bureau of Economic Research

Cambridge, MA 02138

Lynne G. Zucker University of California, Los Angeles Los Angeles, CA 90095 National Bureau of Economic Research Cambridge, MA 02138

Andrew J. Wang Advanced Technology Program National Institute of Standards and Technology Gaithersburg, MD 20899

December 2002

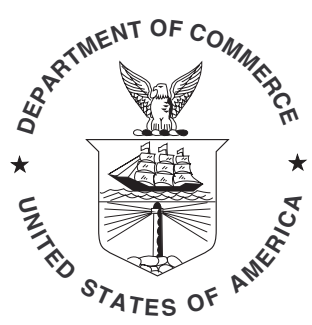

U.S. DEPARTMENT OF COMMERCE Donald L. Evans, Secretary

TECHNOLOGY ADMINISTRATION Phillip J. Bond, Under Secretary of Commerce for Technology NATIONAL INSTITUTE OF STANDARDS AND TECHNOLOGY Arden L. Bement, Jr., Director 



\begin{abstract}
This study finds that the Advanced Technology Program (ATP) has a positive effect on innovation in firms. Participation in ATP projects increases firms' patenting, relative to patenting by the same firms prior to the ATP award. For firms analyzed in this study, covering ATP award years 1990-1995, patenting increased on average by between 5 and 30 patents each year during the period of ATP project participation. Furthermore, both joint venture project participation and university participation in a project appear to have a positive impact on firm patenting. Joint ventures or alliances between firms are expected to have a positive effect on innovation outcomes through the sharing of research capabilities and expertise, and through increased networking and learning. University collaborations are expected to have a positive impact on innovation due to sharing of knowledge and expertise.
\end{abstract}




\section{Acknowledgments}

We thank the University of California Industry-University Cooperative Research Program, especially its director, Dr. Susanne L. Huttner, for providing support to obtain licenses to limited-use data, and to develop a "fuzzy matching" algorithm. The support provided for the data at the Institute on Primary Resources (IPR) at UCLA, and allowed us to match ATP participant companies to the data archive. We thank Adam Jaffe for making the Case Western Reserve/NBER patent data through 1996 available to us. We are indebted to a remarkably talented UCLA research team, especially David Johnson, Wenjin Kang, Qiao Liu, David Waguespack, and Xiaogang Wu, and also Stephanie Hwang, Andrew Jing, Henry Tang, and Mo Xiao. We also acknowledge helpful comments and assistance from NIST colleagues John Hewes, Dennis Leber, John Nail, Stephanie Shipp, and Connie Chang in reviewing and producing the final report. 
EXECUTIVE SUMMARY

\section{Executive Summary}

In evaluating the Advanced Technology Program, an important indicator of program success is increased innovation by participant firms. In this study, we measure innovation outcomes by successfully granted patents. First, we measure the overall change in successful patent applications by participant firms during the period of ATP support. Second, we investigate what might explain differing impacts of the ATP on firm success; in particular, we consider the effect of program design. The ATP makes awards for two types of programs: joint venture (JV) projects involving explicit collaboration between two or more firms (and possibly additional organizations such as universities and federal laboratories); and single-firm (SF) projects proposed by individual companies. This study examines the effects of both program structure and university participation on firms.

Besides providing funding awards to participants, the ATP promotes new organizational structures that facilitate innovation. First, the ATP supports firms willing to pursue novel approaches at the technological frontier, and encourages industry to initiate higher-risk projects with greater potential for broader economic impact. Second, the ATP encourages cooperation and collaboration in R\&D activities, among JV partners, and through subcontracting relationships with universities, firms, and other organizations. When selecting, monitoring, and reviewing projects, the ATP emphasizes linkages that are key to innovation and technology transfer among firms and organizations. Because ATP project participation enhances firms' social network for R\&D, we also expect that the impact on innovation outcomes will extend beyond the project level to the firm level. Therefore, we assess the impact of the ATP in before-and-after comparisons of innovation outcomes at the firm level.

The sociological view of the ATP's role in supporting innovation emphasizes the changes in social relationships and behavior that result from firms working together in R\&D. Close contact among researchers in collaborative R\&D is most likely to transmit new knowledge, often tacit in nature, that is close to the R\&D frontier. Relaxation of boundaries around firms increases the flow of information and hence learning across organizations. Institutional structures such as agreements and monitoring can be developed to support trust between organizations, which leads to greater confidence in successful coordination. 
This study conducts a statistical analysis of patenting by firms before and after ATP project participation in order to assess innovation outcomes. The general finding from the analysis is that the ATP has a positive effect on innovation in firms. Participation in ATP projects increases firms' patenting, relative to patenting by the same firms prior to the ATP award. For firms analyzed in this study, covering ATP award years 1990-1995, patenting increased on average by between 5 and 30 patents each year during the period of ATP project participation. Furthermore, the findings of this study support the idea that both joint ventures and university collaboration have a positive impact on innovation, as measured by increases in firm patenting. 


\section{Contents}

Abstract $\ldots \ldots \ldots \ldots \ldots \ldots \ldots \ldots \ldots \ldots \ldots \ldots \ldots \ldots \ldots \ldots \ldots \ldots \ldots \ldots$ iii

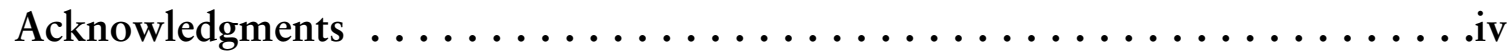

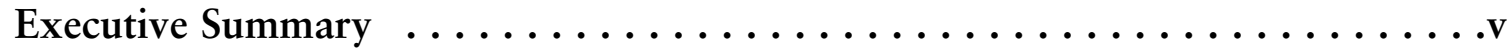

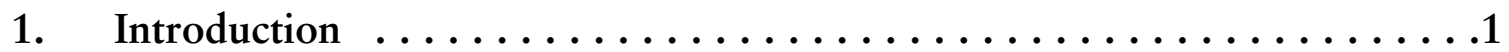

2. ATP Program Design as Institution-Building $\ldots \ldots \ldots \ldots \ldots \ldots \ldots .2$

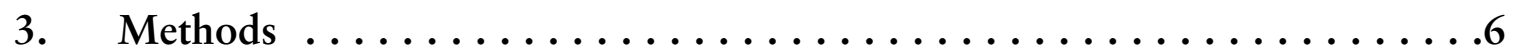

3.1. Sampling Criteria and Panel Design $\ldots \ldots \ldots \ldots \ldots \ldots \ldots$

3.2. Variable Construction $\ldots \ldots \ldots \ldots \ldots \ldots \ldots$

4. Empirical Results: The ATP's Effects on Firm Success $\ldots \ldots \ldots \ldots \ldots 12$

4.1. Effects of ATP Participation on Patenting ..............12

4.2. Separate Effects of Participation and Funding Amount ........12

5. Conclusions and Implications . . . . . . . . . . . . . . . . 19

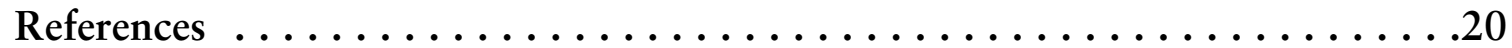

About the Advanced Technology Program . . . . . . . . . . inside back cover

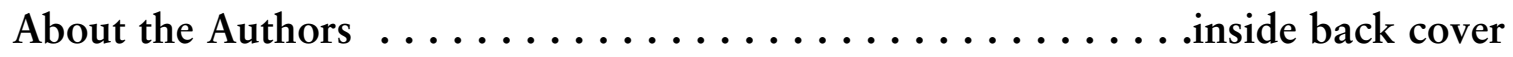

List of Tables

Table 1. Firms in ATP Projects (1990-1995), Panel Dataset . . . . . . . . . 9

Table 2. Firms in ATP Projects (1990-1995), by Size . . . . . . . . . . . . 9

Table 3. Descriptive Statistics for Regression Sample of ATP Firms . . . . . . 11

Table 4. Patenting by All Firms: Type of ATP Project Participation-

OLS Regression ...........................

Table 5. Patenting by All Firms: Intensity of ATP Project ParticipationOLS Regression .........................15

Table 6. Patenting by All Firms: Intensity of ATP Project ParticipationFixed Effects Regression .......................17 
Program Design and Firm Success in the ATP

Table 7. Patenting by Public Firms: Intensity of ATP Project Participation-

OLS Regression .........................

Table 8. Patenting by Public Firms: Intensity of ATP Project Participation-

Fixed Effects Regression ........................19

\section{List of Figures}

Figure 1. Number of Projects and Firm Participants, and Cumulative Number of Unique Firm Participants . . . . . . . . . . . . . . . . .7

Figure 2. ATP Projects and Participants, by Single Firm and Joint Venture Type, 1990-1998 . . . . . . . . . . . . . . . . . . . . . . .7

Figure 3. Distribution of Firms in ATP Projects (1990-1995), by Type of University Participation . . . . . . . . . . . . . . . . 10

Figure 4. Estimated Increase in Patents per Year, by Type of Participation . . . 16

Figure 5. Estimated Increase in Patents per Year, by Type of University Role . .16 
INTRODUCTION

\section{Introduction}

The Advanced Technology Program (ATP) at the National Institute for Standards and Technology (NIST) funds the development of enabling technologies that firms are not likely to pursue in a timely way without the ATP. The role of ATP is to bridge the gap from demonstrating a promising but risky idea to garnering the organizational and financial resources to develop and commercialize a product or process. In doing so, ATP increases the prospect of commercial introduction of advanced technology. The ATP made its first awards in 1990, based on peerreviewed proposals submitted by either individual firms or joint ventures of two or more collaborating firms. Over its twelve-year history, ATP has made over 600 awards involving well over 1,000 participants and subcontractors.

A key element of program success for the ATP is that it contributes to innovation success of participant firms: If participant firms do not innovate and benefit from new technology, others are less likely to benefit from new technology. Hence, as a first step in evaluating program success, we search for evidence of ATP's overall impact on firm success. Our second step in evaluation is to investigate what might explain differing impact on firm success; in particular, we consider the effect of program design. The ATP makes awards for two types of programs: projects that explicitly involve collaboration between two or more firms (and possibly additional organizations such as universities and federal laboratories); and projects proposed by individual firms that include no formal collaborative framework. The former we term as joint venture or JV projects, and the latter we term as single firm or SF projects. Our study examines effects on firms' outcomes related to these differing project structures, as well as effects related to participation by universities (as a full member in a JV, or as a subcontractor in either an SF or JV project).

We evaluate the ATP's effects in terms of overall change in successful patent applications before and during the period of ATP support. Patents are a useful measure of innovation for all ATP participants, including small, privately held firms, larger public firms, universities, and other research organizations. From 1988 to 1996, ATP participant firms and organizations accounted for over 40 percent of all patents granted to U.S. entities by the U.S. Patent and Trademark Office (USPTO). Public and private firms comprise 88 percent of all ATP participants, and account for over 80 percent of patents awarded to all ATP participants. Patenting of innovations in advanced technology appears to be important to most firms and organizations participating in the ATP. 
Program Design and Firm Success in the ATP

In our view, the ATP not only provides funding awards, but also fosters "institution-building" by promoting new organizational structures among applicants and participants which help to facilitate innovation-which is the capture of inventions in technologically advanced commercial products. Institution-building takes place through the ATP in a number of ways. First, the ATP supports firms willing to experiment and develop approaches that are novel and at the technological frontier. Industry is thereby stimulated to initiate projects that are higher in technical risk and have greater potential for broader economic impact. Second, ATP encourages cooperation and collaboration in R\&D activities, among JV partners, and through subcontracting relationships with universities, firms, and other organizations. When selecting, monitoring, and reviewing projects, the ATP emphasizes linkages that are key to innovation and technology transfer among firms and organizations.

In social science terminology, ATP project participation changes participants' "social embeddedness" in networks of relations with other firms and organizations. While this effect may be especially prominent for joint venture participants, firms in single firm projects also note the importance of R\&D subcontractors and relationships for achieving project objectives. Because ATP project participation enhances firms' social network for R\&D, we also expect that the impact on innovation outcomes will extend beyond the project level to the firm level. Therefore, we assess the impact of the ATP in before-and-after comparisons of innovation outcomes at the firm level.

\section{ATP Program Design as Institution-Building}

The "social embeddedness" perspective on economic behavior of individuals and firms emphasizes the social context and interactions of economic actors. In traditional economic theory, economic behavior is analyzed in terms of rational choice and utility-maximizing individuals or profit-maximizing firms, and relatively little emphasis is placed on specific historical and social contexts. Sociologists, on the other hand, have emphasized the importance of understanding how specific social relationships shape economic behavior and economic outcomes. Economic behavior is embedded in a social context, and the characteristics of particular social relations affect economic behavior and determine economic outcomes (Granovetter 1985). When disputes arise in business, they are "frequently settled without reference to the contract or potential or actual legal sanctions" (Macaulay 1963: 61). Instead, personal relationships based on cooperation and trust are important to solving problems 
and reaching agreements. Similarly, subcontracting or sales and purchasing decisions are often made on the basis of long-term relationships and ongoing social interactions or networks.

When the ATP makes an award and funds a project, the participating firms and other organizations establish R\&D and business ties, thus extending and enhancing their social network for innovation. By fostering organizational interactions, the ATP helps build and further develop the institutional basis for innovation. From their networks, firms gain access to knowledge and complementary expertise of R\&D partners, as well as business and marketing resources of partner firms. The social-embeddedness perspective on R\&D and innovation emphasizes that ATP project participation is an active institutionbuilding process. Firms partner with other firms and organizations, with support from the ATP, in order to establish R\&D arrangements that are favorable to highrisk research, and conducive to socially beneficial modes of behavior such as research cooperation and information sharing.

We highlight below a few aspects of social embeddedness-social relations that structure economic behavior and outcomes-that are particularly important aspects of ATP's institution-building:

- Close collaboration among researchers in R\&D work. Such relationships are most likely to transmit new knowledge, often tacit in nature, which is close to the knowledge frontier (Zucker et al. 1998a).

- Relaxation of boundaries around the firm. Cross-firm interaction and knowledge transfer is accepted because information gains are expected to be sufficiently valuable to offset any losses of proprietary information (Zucker et al. 1996). Boundary permeability allows more flow of information and hence more learning across organizations than would otherwise be the case. Boundary design is often part of the strategic arsenal of a firm (Helper et al. 1998).

- Development of institution-based trust. Trust between organizations can be developed on the basis of institutional structures rather than interpersonal or specific characteristics of the other party (Zucker 1986). Two examples of institution-based trust fostered by the ATP include: (1) Third-party (ATP) monitoring of participants' behavior in joint ventures to ensure cooperation (see Zucker et al. 1996); and (2) Administrative structures and agreements (such as intellectual property agreements and JV administrative structures) to increase confidence in successful coordination (see Das and Teng 1998).

We believe that the implicit design of the ATP fosters firm behaviors that are socially beneficial and in the collective interest, in particular encouraging firms to collaborate and share knowledge. Sociology theory argues that actors contribute 
Program Design and Firm Success in the ATP

to a collective good when two conditions are met: first, their action is likely to have efficacy - that is, be effective; and second, there are norms of fairness that encourage them to match the contributions of others (Gould 1993). The ATP provides an institutional structure that makes efficacy and fairness more likely. First, ATP projects define and structure the collective benefits expected from research collaboration. Second, ATP project participation builds experience with R\&D collaboration, and hence norms for collaborative work. Firms participating in ATP benefit not only from the R\&D project per se, but also from the R\&D experience. In other words, firms benefit from “technology learning," which relates to the actual R\&D work, and also from "organizational learning," which relates to the organizational processes for initiating and managing R\&D.

ATP institution-building is also evident in the ATP guidelines for structuring projects and partners to maximize research synergy. For example, ATP encourages including a variety of different types of JV partners in order to further prospects for R\&D success and technology commercialization and diffusion: "Joint ventures should aim to include companies of diverse size, including smaller companies, and possibly other organizations, such as universities and national laboratories" (ATP 1999: 34). Of particular interest is that many ATP projects involve universities. Universities are often at the center of new discoveries, especially discoveries that represent radical change from prior knowledge (see Jaffe 1989; Liebeskind et al. 1996; Zucker and Darby 1996; Zucker et al. 1998). As such, university relationships may be important to many ATP projects.

The ATP has an express mission of encouraging collaborations among firms, and between firms, universities, and other federal and non-profit research organizations that make up the innovation network in the United States. The ATP supports JVs with project awards that include potentially higher award levels over more years of funding than SF projects. The ATP requires that JVs establish an agreement and governance structures for management of the JV. The ATP also encourages knowledge sharing among JV members. In effect, JVs tend to relax the boundaries of participants' organizations. Joint governance, collaborative R\&D work, and joint access to intellectual property created within the JV all have the effect of opening up boundaries. Knowledge "spillovers" or transfers of knowledge to other JV members occur within the enlarged "information envelope" that encompasses the JV (Zucker et al. 1996). In particular, internal task routines that are especially difficult to observe from outside of organizations may be transferred among members within the expanded boundaries (see Nelson and Winter 1982: 123-124).

Expanding the effective boundaries of organizations to encompass new research collaborations results in greater information sharing by two means. Firstly, in JVs, 
knowledge created by one participant organization becomes more observable to other participants-internal task routines that are often unobservable across organizational boundaries become transparent through joint work among scientists, engineers, and other technically trained workers. And secondly, JV collaboration defines a new "commons," an area of mutual benefit around the shared project, which draws in additional shared resources and establishes additional collaboration and information sharing.

Our thesis is that JV participants operate in—are "embedded in"—a different social context as a consequence of participating in a JV through an ATP award. The JV participant organizations have changed social relationships (more contacts and different contacts). These relationships provide an expanded information network, and increased knowledge transfer through learning processes (Doz 1996; Hamel 1991).

The expanded JV learning context includes firms, universities, federal labs, and organizations outside of the JV-other organizations that the JV partners collaborate with or are linked to in some way. These connections multiply access to other kinds of knowledge, which provides additional expanded information advantage, an example of the "strength of weak ties" in social networks (Granovetter 1973). JVs organized in order to apply for ATP funding often bring together firms that have not worked together before. Even more, each JV partner brings contacts that are new to the other JV members.

Comments by ATP participants in JVs support the idea that collaboration expands knowledge transfer among different organizations, and expands contacts across a wider network of potential partners. As one JV participant states:

Excellent collaborative environment and complementary technical capabilities have improved the quality of technical output and effectiveness of the team. There has been tremendous synergy between the companies that are collaborating on this project. Each company brings a particular expertise that the others don't have and which would be difficult to develop. Each party is an enabler for the others. (Powell and Lellock 2000: 23)

As another JV participant indicates:

In general, the collaboration has allowed us to contact new potential collaborators and markets. Some of these markets are for new equipment using our technology in ways we had not considered. Due to the success of the JV, the various members are investigating projects outside the ATP. (Powell and Lellock 2000: 25) 
Program Design and Firm Success in the ATP

\section{Methods}

Institution-building by the ATP and the resulting organizational and informational advantages held by ATP participants are factors that enter into the innovation process in ATP projects. How do we best measure the impact of ATP participation? To assess changes in organizational learning and knowledge through ATP projects, we will study and compare change in innovation outcomes before and after ATP participation. A major purpose of the ATP is to increase commercial introduction of advanced technology by accelerating the development of high-risk, enabling technologies. Patents, in representing an active business decision to protect commercially valuable inventions, are arguably the single best proxy measure of innovation. Patents are in fact commonly used to protect intellectual property created with ATP support: 76 percent of organizations report that patenting is a primary or secondary strategy for protecting intellectual property, with only 12 percent reporting that patenting is unlikely (Powell and Lellock 2000: 43).

In the analysis to follow, we assess whether ATP projects have a more general effect on formation of new intellectual property within the firm as a whole. An ATP project may represent only one R\&D effort among many at a firm; but to the extent that ATP involvement changes firm behavior, institutional settings, or social embeddedness, the impact of the ATP project may extend beyond the project to affect the firm more generally. Our key indicator of impact on firm innovation is whether the overall rate of patenting by a firm increases after participation in ATP projects begins. We focus on project structure (joint venture vs. single firm), and university participation (university partner in a JV project, and university subcontractor in a JV or SF project). We use a patent count measure based on archival data assembled by the National Bureau of Economic Research (NBER) and Case Western University, and significantly augmented by the Center for International Science, Technology, and Cultural Policy (CISTCP) at UCLA.

Our first step is to set the unit of analysis. Archival data on patents are generally available only for the firm or organization as a whole, and not for specific locations of multi-location firms. Our analysis of whether participation in the ATP has a positive effect on firms is therefore centered on the firm/organization as the basic unit of analysis. Figure 1 shows the number of ATP projects and firm participants from ATP award years 1990-1998. Figure 2 shows the distribution by SF or JV type for projects and all participants, from ATP award years 1990-1998. The number of single firm projects is about twice the number of joint venture projects. But because joint ventures involve multiple participants, the number of JV participants is more than twice the number of SF participants. 
Figure 1. Number of Projects and Firm Participants, and Cumulative Number of Unique Firm Participants

Number of projects

Cumulative number of and firm participants unique firm participants

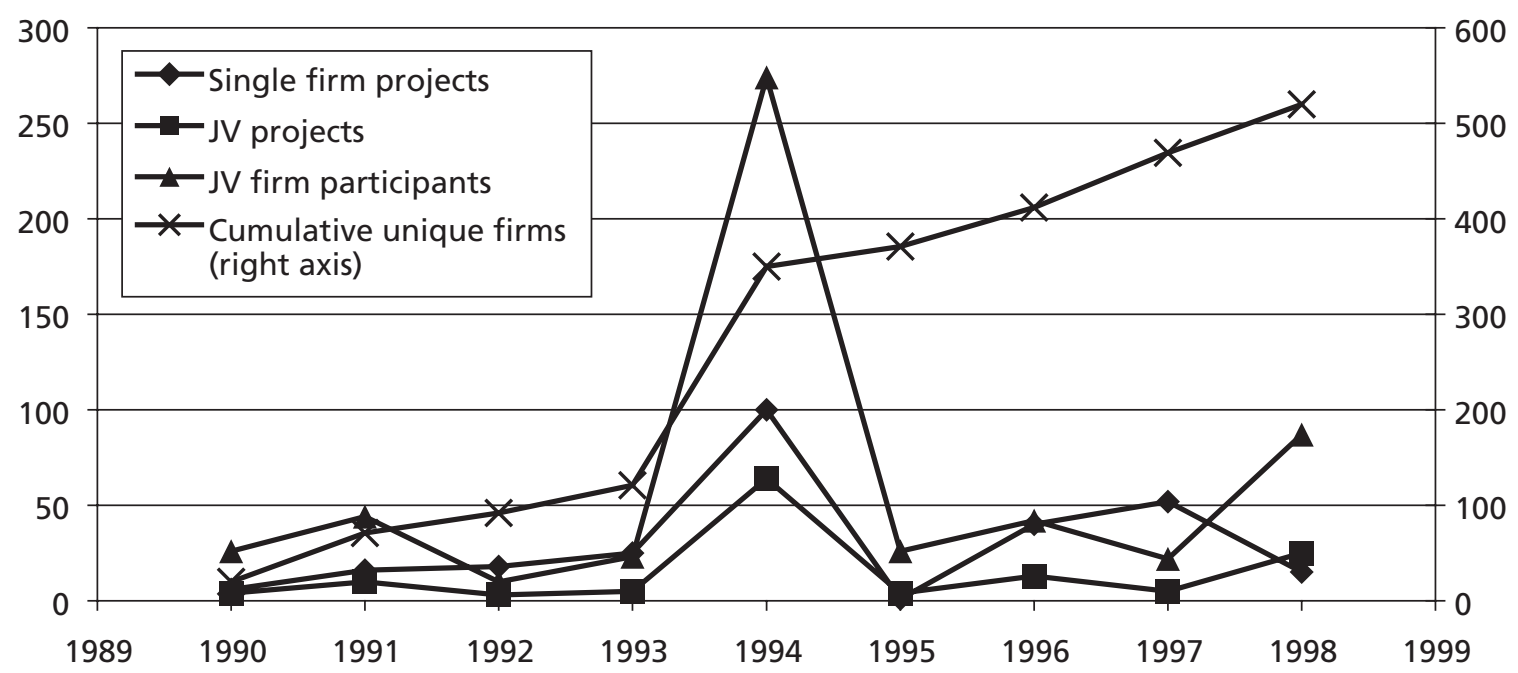

Figure 2. ATP Projects and Participants, by Single Firm and Joint Venture Type, 1990-1998

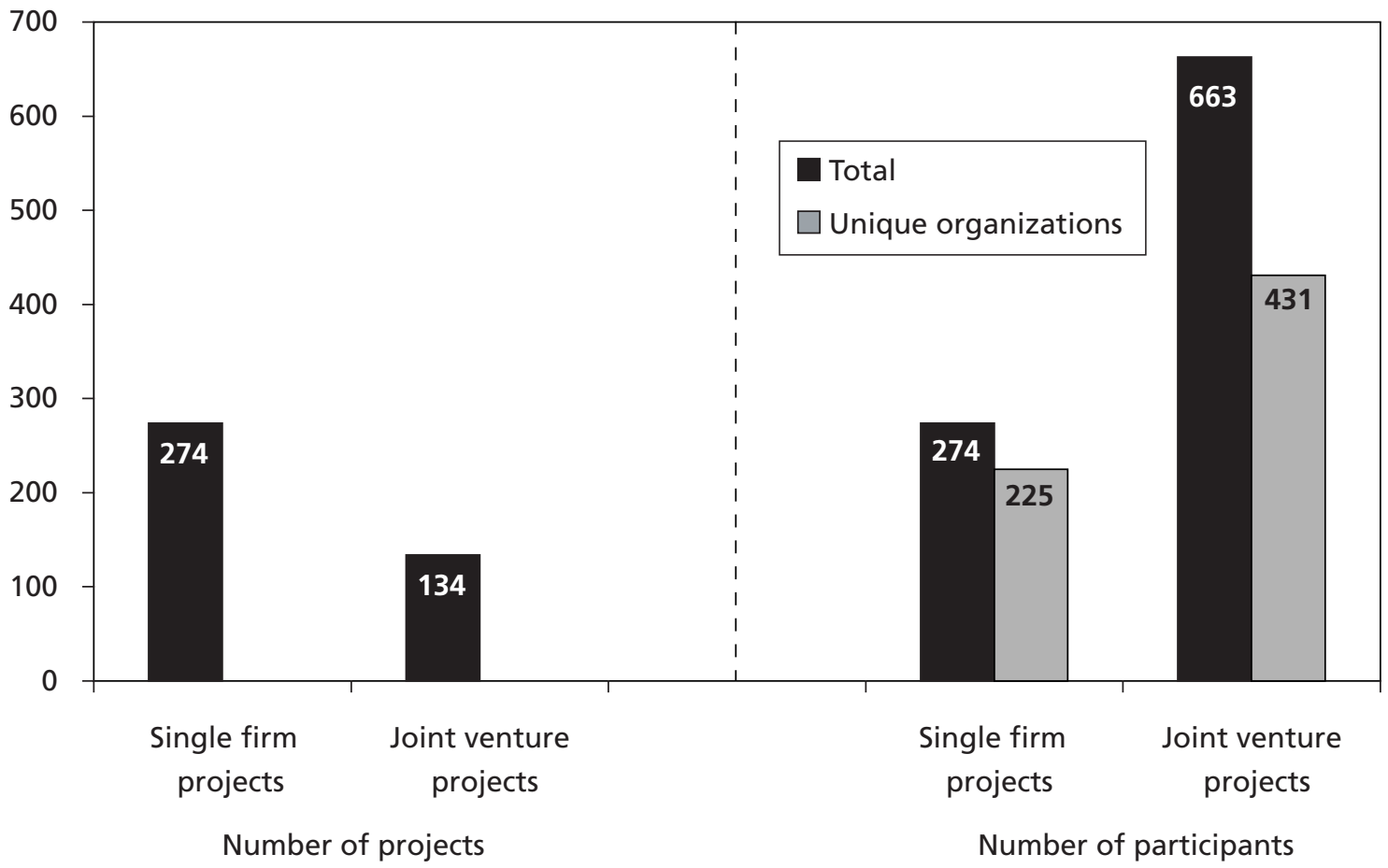


Program Design and Firm Success in the ATP

Some firms/organizations have participated in more than one ATP project, and some have been in both JV and SF projects. So Figures 1 and 2 also present the total number of "unique" firms or organizations, which counts each firm/organization only once, even if it has been a participant in more than one ATP project.

\subsection{Sampling Criteria and Panel Design}

Patenting by ATP awardee firms is tracked before, during, and after they become ATP participants, allowing us to assess patenting performance for periods with and without ATP support. In this way, an ATP participant can serve as its own comparison group. For our analysis we include all firms conducting R\&D in projects that started by the end of 1995. (We exclude participants involved only in administrative functions, and participants involved only in projects cancelled before completion.) Firms enter our analysis panel in the year the firm was founded, or in the first year of our panel, 1988, if the firm was founded before 1988. We chose 1988 as the first year for the panel to allow for pre-ATP observation years, even for firms entering in the first ATP cohort (1991). The panel ends in 1996 because number of patents dated by year of application is our key variable of interest. By 1997 the count of patents by year of application becomes truncated, because many patent applications from 1997 have yet to emerge from the patent process, given that our data on patents granted ends June 30, 1999.

Table 1 presents the panel structure for two samples of firms. In order to match to patent data, multiple establishments of the same firm are counted as one unit, even though different locations of a firm may be participating at different times in the ATP. The first sample is all firms that have participated in the ATP, and the second sample is publicly traded firms that have participated in the ATP. New entrants to the panel, in years other than the first year of the panel, are due to founding of a new firm. Table 2 shows the distribution of firms by size category.

We establish a hierarchy to define firms as joint venture or single firm, with or without university partner:

- If a firm has been a full partner in a JV project from ATP award years 1990-1995, then it is considered to be a "JV firm."

- JV firms that have had both a university partner and a university subcontractor in this period are defined as "JV firm-university partner and subcontractor."

- JV firms that have had only a university partner or only a university subcontractor are defined as "JV firm-university partner" or "JV firmuniversity subcontractor." 
Table 1. Firms in ATP Projects (1990-1995), Panel Dataset A. All Firms in ATP Projects

\begin{tabular}{lrrrrrrrrr}
\hline Year & 1988 & 1989 & 1990 & 1991 & 1992 & 1993 & 1994 & 1995 & 1996 \\
\hline Total firms & 232 & 245 & 260 & 274 & 285 & 349 & 349 & 350 & 350 \\
Active in ATP & 0 & 0 & 0 & 20 & 71 & 90 & 117 & 341 & 319 \\
Not active in ATP & 232 & 245 & 260 & 254 & 214 & 259 & 232 & 9 & 31
\end{tabular}

B. Public Firms in ATP Projects*

\begin{tabular}{lccrrrrrrr}
\hline Year & 1988 & 1989 & 1990 & 1991 & 1992 & 1993 & 1994 & 1995 & 1996 \\
\hline Total firms & 93 & 96 & 99 & 108 & 116 & 122 & 131 & 151 & 151 \\
Active in ATP & 0 & 0 & 0 & 6 & 36 & 45 & 56 & 149 & 137 \\
Not active in ATP & 93 & 96 & 99 & 102 & 80 & 77 & 75 & 2 & 14 \\
\hline
\end{tabular}

"Public firms are defined as firms appearing in the Standard \& Poor's Compustat database of publicly traded firms.

Table 2. Firms in ATP Projects (1990-1995), by Size

\begin{tabular}{cccccc}
\hline & \multicolumn{2}{c}{ All firms } & & \multicolumn{2}{c}{ Public firms } \\
$N=350$ & & & \multicolumn{2}{c}{ N=158 } \\
\cline { 2 - 3 } \cline { 5 - 6 } & Freq. & $\%$ & & Freq. & $\%$ \\
\hline Small & 195 & 56 & 57 & 36 \\
Medium & 88 & 25 & & 47 & 30 \\
Large & 67 & 19 & & 54 & 34 \\
\hline
\end{tabular}

Small $=$ fewer than 500 employees

Medium $=500$ employees or greater, but not Fortune 500 firm

Large $=$ Fortune 500 firm

- The remaining JV firms are defined as "JV firm—no university."

- Single-participant firms are classified as either "Single firm-university subcontractor" or "Single firm—no university."

Figure 3 shows that nearly three quarters of all firms in ATP projects have had university partners or subcontractors.

\subsection{Variable Construction}

Our analysis of ATP impact is based on measurement of changes in patenting success by firms during and after participation in the ATP. The overall rate of patenting depends on the "propensity to patent," which is affected by the value of 
Program Design and Firm Success in the ATP

Figure 3. Distribution of Firms in ATP Projects (1990-1995), by Type of University Participation

All Firm Participants

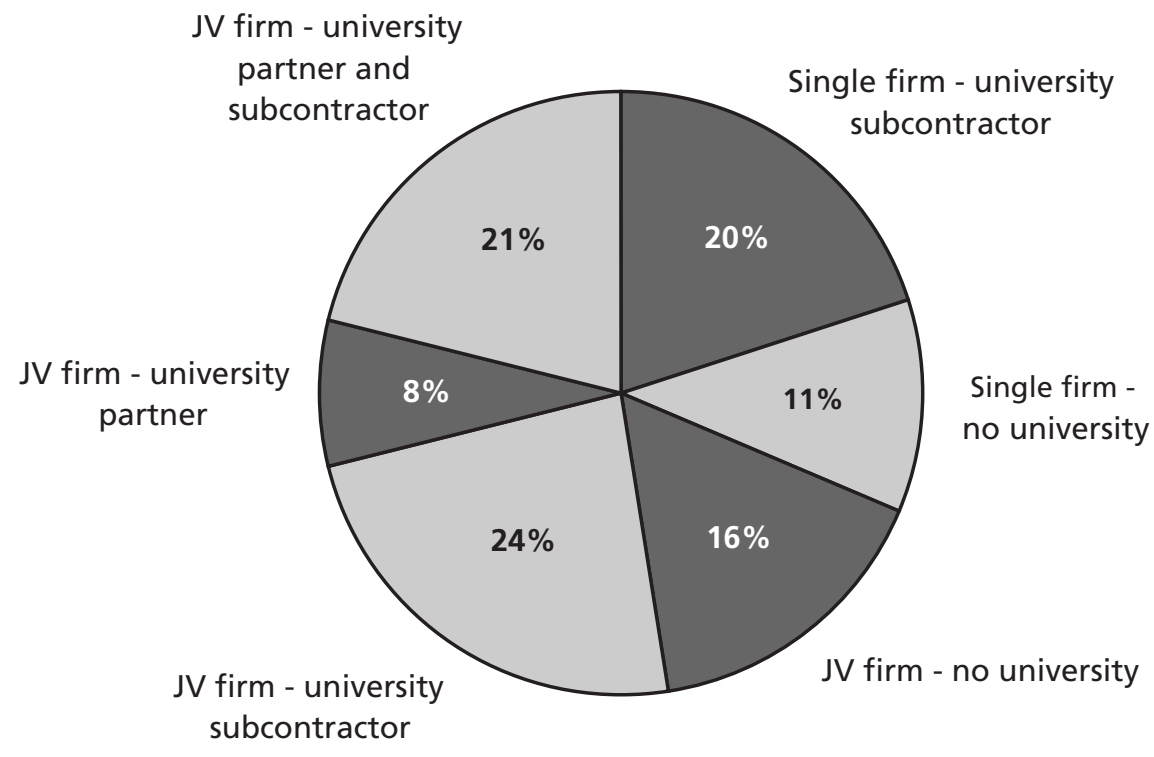

getting a patent and the ease of obtaining a patent (Griliches 1990). In recent years, the U.S. Congress and the courts have strengthened patent rights, and the U.S. Patent and Trademark Office has hired more patent examiners. As a result, both the rate of patent application and the speed with which patents are granted have increased. A simple before-and-after comparison of patenting is therefore subject to the criticism that it reflects trend increases in patenting rather than identifying real program impact. Accordingly, we develop a "deflated" patentcount measure, which adjusts for year-to-year changes in the average rate of patenting, measured by average number of "patents per assignee" for all U.S. assignees of U.S. patents.

All dollar amounts (that is, ATP award amounts and company cost-share amounts, as well as R\&D expenditures for public firms) are deflated to 1996 dollars using the GDP deflator. We construct an R\&D stock variable to measure the cumulated "R\&D capital" of the firm. Annual R\&D expenditures are available for public firms from the Standard and Poor's Compustat database of publicly traded firms. Annual R\&D expenditures are cumulated and discounted to produce the R\&D stock variable.

Table 3 provides descriptive statistics for the variables used in the empirical analysis for three groups of ATP participants: (1) All firm participants; (2) public 
firm participants, defined as firms appearing in the Compustat database; and (3) all organization participants, including universities and other nonprofits in JV projects. The firm size categories are based on ATP definitions of firm size (as shown in Table 2). The technology area categories are based on ATP definitions of the technology area of the ATP project.

Table 3. Descriptive Statistics for Regression Sample of ATP Firms

\begin{tabular}{|c|c|c|c|c|}
\hline \multirow[b]{2}{*}{ Variable } & \multicolumn{2}{|c|}{$\begin{array}{l}\text { All firms } \\
N=2694\end{array}$} & \multicolumn{2}{|c|}{$\begin{array}{c}\text { Public firms } \\
\text { N=1067 }\end{array}$} \\
\hline & Mean & S. D. & Mean & S. D. \\
\hline \multicolumn{5}{|l|}{ DEPENDENT VARIABLE } \\
\hline Patents, deflated ${ }^{\mathrm{a}}$ & 39.35 & 141.83 & 87.37 & 206.93 \\
\hline \multicolumn{5}{|l|}{ ATP PARTICIPATION INDICATORS } \\
\hline ATP participant ${ }^{b}$ & 0.29 & 0.42 & 0.33 & 0.44 \\
\hline ATP JV participant ${ }^{b}$ & 0.20 & 0.37 & 0.26 & 0.42 \\
\hline$J V$ with university partner ${ }^{b}$ & 0.08 & 0.26 & 0.12 & 0.31 \\
\hline$J V$ with university subcontractor ${ }^{b}$ & 0.11 & 0.29 & 0.14 & 0.32 \\
\hline SF with university subcontractor ${ }^{b}$ & 0.07 & 0.24 & 0.08 & 0.25 \\
\hline Cumulative ATP award stock $(\$ 000 \mathrm{~s}) \mathrm{c}$ & 272.39 & 748.74 & 389.78 & $1,020.57$ \\
\hline Cumulative ATP JV award stock $(\$ 000 \mathrm{~s})^{\mathrm{c}}$ & 132.59 & 543.65 & 229.55 & 773.68 \\
\hline \multicolumn{5}{|l|}{ FIRM CHARACTERISTICS } \\
\hline Small firm ${ }^{d}$ & 0.50 & 0.50 & 0.25 & 0.44 \\
\hline Medium firm ${ }^{d}$ & 0.28 & 0.45 & 0.32 & 0.47 \\
\hline Large firm ${ }^{d}$ & 0.22 & 0.41 & 0.43 & 0.49 \\
\hline Biotechnology e & 0.13 & 0.32 & 0.11 & 0.30 \\
\hline Chemicals $\mathrm{e}$ & 0.07 & 0.24 & 0.11 & 0.28 \\
\hline Electronics ${ }^{\mathrm{e}}$ & 0.14 & 0.32 & 0.14 & 0.30 \\
\hline Energy ${ }^{e}$ & 0.04 & 0.18 & 0.05 & 0.19 \\
\hline Information technology ${ }^{\mathrm{e}}$ & 0.23 & 0.41 & 0.21 & 0.39 \\
\hline Manufacturing $\mathrm{e}^{\mathrm{e}}$ & 0.22 & 0.40 & 0.20 & 0.37 \\
\hline Materials $\mathrm{e}$ & 0.17 & 0.35 & 0.18 & 0.34 \\
\hline Cumulative R\&D stock (\$millions) a & - & - & $1,759.78$ & $4,605.06$ \\
\hline
\end{tabular}

Notes:

a. Continuous variable for firm-year.

b. Numerical fraction variable for firm-year: (Number of months during year where participation indicator is True)/ 12 .

c. Continuous variable for firm-year: Sum of monthly pro-rated award amount for firm in year.

d. Indicator variable for firm.

e. Numerical fraction variable for firm-year: Variable defined by technology area of ATP project, and is numerical fraction when firm is in more than one project and technology area of projects differ. 
Program Design and Firm Success in the ATP

\section{Empirical Results: The ATP's Effects on Firm Success}

\subsection{Effects of ATP Participation on Patenting}

Our basic hypotheses concern the effects of ATP participation on patenting. First, we hypothesize that participation in ATP projects has a positive effect on patenting at the firm level; that is, that the benefit of ATP project participation extends beyond the project to the firm level. Second, we hypothesize that participation in JV projects provides greater benefit to firms than participation in SF projects, so we expect the ATP participation effect on firm patenting to be greater for firms in JVs. The argument is that JV membership expands and deepens connections among organizations, which is "social capital" for firm innovation. Third, we hypothesize that the effect of ATP participation on innovation, as measured by firm patenting, is greater if the firm has a university partner or subcontractor. This hypothesis derives from studies that have shown the importance of academia to science-driven industries (Jensen and Thursby 2000; Thursby and Thursby 2000; Zucker and Darby 1996, 1998; Zuckeret al. 1998a, 1998b).

We now turn to our main analysis of the panel of all firms that began participation in the ATP by the end of 1995. In Table 4, we control for firm size and project technology area, and then include dummy variables that describe firms' type of ATP participation in each year. In regression 3.1, we see that ATP participation is associated with an increase of 29 in number of patents awarded to the firm-nearly a 75 percent increase in patenting relative to the mean number of patents per year for firms in the sample. In regression 3.2, we see that ATP JV project participation has a positive effect relative to SF project participation. In regression 3.3, we see that joint ventures with a university partner receive an additional positive effect on patenting, and in regression 3.4 , we see that university subcontractors have a positive effect on firm patenting. We conclude that JV participation and university participation are important to higher rates of patenting by firms in ATP projects.

\subsection{Separate Effects of Participation and Funding Amount}

We can extend our analysis by taking into account the total amount of ATP award funds received, and also the amount received through JV project awards. In this case, the degree or extent of ATP participation (or the intensity of the ATP "treatment effect") is indicated by the amount of ATP award funding received by the firm. Following typical practice in constructing measures of capital, we 
Table 4. Patenting by All Firms: Type of ATP Project ParticipationOLS Regression

\begin{tabular}{|c|c|c|c|c|}
\hline \multirow{2}{*}{$\frac{\text { Dependent variable }}{\text { Specification }}$} & \multicolumn{4}{|c|}{ Patents, by date of application (deflated; one year lag) } \\
\hline & 3.1 & 3.2 & 3.3 & 3.4 \\
\hline Estimation & OLS & OLS & OLS & OLS \\
\hline Constant & $\begin{array}{l}-50.718^{* * *} \\
(10.936)\end{array}$ & $\begin{array}{l}50.561^{* * *} \\
(10.896)\end{array}$ & $\begin{array}{l}-48.298^{* * *} \\
(10.897)\end{array}$ & $\begin{array}{l}-50.300^{* * *} \\
(10.753)\end{array}$ \\
\hline Small & $\begin{array}{r}-13.225^{*} \\
(5.770)\end{array}$ & $\begin{array}{r}-10.952 \\
(5.770)\end{array}$ & $\begin{array}{r}-10.303 \\
(5.762)\end{array}$ & $\begin{array}{c}-9.924 \\
(5.681)\end{array}$ \\
\hline Large & $\begin{array}{c}156.503^{* * *} \\
(7.021)\end{array}$ & $\begin{array}{c}154.309^{* * *} \\
(7.011)\end{array}$ & $\begin{array}{c}153.634^{* * *} \\
(7.001)\end{array}$ & $\begin{array}{c}149.691 \text { *** } \\
(6.916)\end{array}$ \\
\hline Biotechnology & $\begin{array}{l}55.545^{* * *} \\
(12.382)\end{array}$ & $\begin{array}{l}57.723^{* * *} \\
(12.345)\end{array}$ & $\begin{array}{l}53.647^{* * *} \\
(12.384)\end{array}$ & $\begin{array}{l}59.946 \text { *** } \\
(12.233)\end{array}$ \\
\hline Electronics & $\begin{array}{l}99.215^{* * *} \\
(12.176)\end{array}$ & $\begin{array}{l}98.965^{* * *} \\
(12.130)\end{array}$ & $\begin{array}{l}99.200^{* * *} \\
(12.108)\end{array}$ & $\begin{array}{l}102.851^{* * *} \\
(12.023)\end{array}$ \\
\hline Energy & $\begin{array}{l}50.194^{* *} \\
(16.643)\end{array}$ & $\begin{array}{l}54.170^{* * *} \\
(16.604)\end{array}$ & $\begin{array}{l}53.145^{* * *} \\
(16.576)\end{array}$ & $\begin{array}{l}52.123^{* * *} \\
(16.350)\end{array}$ \\
\hline Information technology & $\begin{array}{l}58.400^{* * *} \\
(11.095)\end{array}$ & $\begin{array}{l}58.643^{* * *} \\
(11.054)\end{array}$ & $\begin{array}{l}54.854^{* * *} \\
(11.093)\end{array}$ & $\begin{array}{l}59.365^{* * *} \\
(10.954)\end{array}$ \\
\hline Manufacturing & $\begin{array}{l}41.138^{* * *} \\
(11.180)\end{array}$ & $\begin{array}{l}37.514^{* * *} \\
(11.166)\end{array}$ & $\begin{array}{c}34.262^{* *} \\
(11.189)\end{array}$ & $\begin{array}{l}35.801 * * * \\
(11.031)\end{array}$ \\
\hline Materials & $\begin{array}{l}50.952^{* * *} \\
(11.831)\end{array}$ & $\begin{array}{l}49.001 * * * \\
(11.795)\end{array}$ & $\begin{array}{l}47.263^{* * *} \\
(11.785)\end{array}$ & $\begin{array}{l}48.703^{* * *} \\
(11.628)\end{array}$ \\
\hline ATP participant & $\begin{array}{l}28.867^{* * *} \\
(5.701)\end{array}$ & $\begin{array}{c}-4.844 \\
(9.279)\end{array}$ & $\begin{array}{c}-4.980 \\
(9.262)\end{array}$ & $\begin{array}{l}-70.538^{* * *} \\
(12.422)\end{array}$ \\
\hline ATP JV participant & & $\begin{array}{l}48.334^{* * *} \\
(10.520)\end{array}$ & $\begin{array}{l}31.871^{* *} \\
(11.625)\end{array}$ & $\begin{array}{l}68.127^{* * *} \\
(15.131)\end{array}$ \\
\hline JV with university partner & & & $\begin{array}{l}38.438^{* * *} \\
(11.645)\end{array}$ & $\begin{array}{c}26.327^{*} \\
(11.579)\end{array}$ \\
\hline JV with university subcontractor & & & & $\begin{array}{l}47.057^{* * *} \\
(11.545)\end{array}$ \\
\hline SF with university subcontractor & & & & $\begin{array}{l}101.406^{* * *} \\
(13.210)\end{array}$ \\
\hline Adjusted R-squared & $0.239 * * *$ & $0.245^{* * *}$ & $0.247^{* * *}$ & $0.269^{* * *}$ \\
\hline $\mathrm{N}$ & 2694 & 2694 & 2694 & 2694 \\
\hline
\end{tabular}

Significance levels: $* \mathrm{p} \leq .05, * \mathrm{p} \leq .01, * * \mathrm{p} \leq .001$

cumulate these funds over time, incorporating a depreciation rate of 20 percent per year, to create an ATP award stock variable. For firms that have participated only in JV projects, the total award stock and JV award stock variables will be equal, while for firms that have participated in both SF and JV projects, the total award stock variable will sometimes be greater than the JV award stock variable. The measured effect on patenting of an additional dollar of SF award funding is equal to the coefficient on the total award stock variable, while the measured 
Program Design and Firm Success in the ATP

effect on patenting of an additional dollar of JV award funding is equal to the sum of the coefficients on the total award stock and JV award stock variables.

Table 5 reports results for regressions that include firm size and technology area controls, ATP participation and JV participation variables, ATP award stock and JV award stock variables, and several university involvement variables. Interpreting the regression results is somewhat complicated. First, estimates for the effect of ATP participation on patenting must be presented by specific category of participant (such as JV with university partner) at the sample mean for the category. Second, because the ATP award stock variable is a stock variable, the effect of participation persists beyond the period of active participation. In Figures 4 and 5, the left bar in each pair presents a conservative interpretation of regression 4.4 by showing the estimated increase in patenting within the sample period for the indicated groups. (The estimates of patenting increases per year of participation are computed by multiplying the relevant coefficients for ATP participation and award stocks by the sample means for each of the specified groups, summing the results, and dividing by the mean number of years of participation.) The estimate is conservative in that only about one-third of the full effect from the award-stock variables occurs within the sample period. Even under this conservative approach, we estimate that the average ATP participant firm increases its patenting by 34 patents per year of ATP participation during the sample period. Thus, even without allowing for the future effects of knowledge created under the ATP program, we find a very substantial effect on patenting attributable to ATP participation. There is also evidence that the effect on patenting is greater for those firms that partner with universities during their ATP participation.

Table 6 and the right bar in each pair in Figures 4 and 5 present results from similar regressions with fixed effects for each firm to control for all unobserved firm-specific heterogeneity. We find an average increase in patenting by 6 patents per year of ATP participation during the sample period.

Tables 7 and 8 present results from similar regressions for the subsample of firms that are publicly traded. For these firms we have data to compute a cumulated R\&D stock variable in the same way as the ATP award stock variable. For these publicly traded firms, the regular and fixed-effect regressions produce estimates of increase in patents by 19 patents and 5 patents per year of ATP participation during the sample period. 
Table 5. Patenting by All Firms: Intensity of ATP Project ParticipationOLS Regression

\begin{tabular}{|c|c|c|c|c|}
\hline \multirow{2}{*}{$\frac{\text { Dependent variable }}{\text { Specification }}$} & \multicolumn{4}{|c|}{ Patents, by date of application (deflated; one year lag) } \\
\hline & 4.1 & 4.2 & 4.3 & 4.4 \\
\hline Estimation & OLS & OLS & OLS & OLS \\
\hline Constant & $\begin{array}{l}-46.904^{* * *} \\
(10.960)\end{array}$ & $\begin{array}{l}-41.265^{* * *} \\
(10.511)\end{array}$ & $\begin{array}{l}-40.674^{* * *} \\
(10.399)\end{array}$ & $\begin{array}{c}-40.404^{* * *} \\
(10.399)\end{array}$ \\
\hline Small & $\begin{array}{r}-11.907^{*} \\
(5.790)\end{array}$ & $\begin{array}{c}-14.556^{* *} \\
(5.536)\end{array}$ & $\begin{array}{r}-12.329^{*} \\
(5.498)\end{array}$ & $\begin{array}{r}-11.577^{*} \\
(5.483)\end{array}$ \\
\hline Large & $\begin{array}{c}159.125^{* * *} \\
(7.034)\end{array}$ & $\begin{array}{c}143.168^{* * *} \\
(6.792)\end{array}$ & $\begin{array}{c}139.682^{* * *} \\
(6.740)\end{array}$ & $\begin{array}{c}138.768^{* * *} \\
(6.720)\end{array}$ \\
\hline Biotechnology & $\begin{array}{l}59.906^{* * *} \\
(12.408)\end{array}$ & $\begin{array}{l}46.164^{* * *} \\
(11.895)\end{array}$ & $\begin{array}{l}48.746^{* * *} \\
(11.776)\end{array}$ & $\begin{array}{l}48.063^{* * *} \\
(11.835)\end{array}$ \\
\hline Electronics & $\begin{array}{l}104.810^{* * *} \\
(12.181)\end{array}$ & $\begin{array}{l}79.819^{* * *} \\
(11.750)\end{array}$ & $\begin{array}{l}77.738^{* * *} \\
(11.629)\end{array}$ & $\begin{array}{l}82.578^{* * *} \\
(11.689)\end{array}$ \\
\hline Energy & $\begin{array}{l}53.224^{* * *} \\
(16.709)\end{array}$ & $\begin{array}{c}38.722^{*} \\
(15.985)\end{array}$ & $\begin{array}{l}42.009^{* *} \\
(15.836)\end{array}$ & $\begin{array}{l}42.248^{* *} \\
(15.789)\end{array}$ \\
\hline Information technology & $\begin{array}{l}61.732^{* * *} \\
(11.127)\end{array}$ & $\begin{array}{l}52.236^{* * *} \\
(10.652)\end{array}$ & $\begin{array}{l}51.705^{* * *} \\
(10.540)\end{array}$ & $\begin{array}{l}50.649 * * * \\
(10.587)\end{array}$ \\
\hline Manufacturing & $\begin{array}{l}44.145^{* * *} \\
(11.215)\end{array}$ & $\begin{array}{l}40.375^{* * *} \\
(10.726)\end{array}$ & $\begin{array}{l}35.867^{* * *} \\
(10.639)\end{array}$ & $\begin{array}{l}33.421 * * \\
(10.644)\end{array}$ \\
\hline Materials & $\begin{array}{l}52.779 * * * \\
(11.880)\end{array}$ & $\begin{array}{l}45.644^{* * *} \\
(11.356)\end{array}$ & $\begin{array}{l}42.447^{* * *} \\
(11.244)\end{array}$ & $\begin{array}{l}42.398^{* * *} \\
(11.228)\end{array}$ \\
\hline ATP participant & & $\begin{array}{c}-20.843^{* * *} \\
(6.365)\end{array}$ & $\begin{array}{l}-95.280 * * * \\
(11.485)\end{array}$ & $\begin{array}{c}-104.890 \text { *** } \\
(12.840)\end{array}$ \\
\hline Cumulative ATP award stock (\$000s) & & $\begin{array}{l}0.056^{* * *} \\
(0.004)\end{array}$ & $\begin{array}{l}0.090^{* * *} \\
(0.007)\end{array}$ & $\begin{array}{l}0.083^{* * *} \\
(0.008)\end{array}$ \\
\hline ATP JV participant & & & $\begin{array}{l}97.561 * * * \\
(12.632)\end{array}$ & $\begin{array}{l}76.474^{* * *} \\
(15.751)\end{array}$ \\
\hline Cumulative ATP JV award stock (\$000s) & & & $\begin{array}{l}-0.051 \text { *** } \\
(0.010)\end{array}$ & $\begin{array}{l}-0.045^{* * *} \\
(0.010)\end{array}$ \\
\hline JV with university partner & & & & $\begin{array}{c}31.973^{* *} \\
(11.208)\end{array}$ \\
\hline JV with university subcontractor & & & & $\begin{array}{l}30.554^{* *} \\
(11.254)\end{array}$ \\
\hline SF with university subcontractor & & & & $\begin{array}{c}26.104 \\
(14.008)\end{array}$ \\
\hline Adjusted R-squared & $0.232 * * *$ & $0.300^{* * *}$ & $0.315^{* * *}$ & $0.320 * * *$ \\
\hline $\mathrm{N}$ & 2694 & 2694 & 2694 & 2694 \\
\hline
\end{tabular}

Significance levels: $* \mathrm{p} \leq .05, * \mathrm{p} \leq .01, * * \mathrm{p} \leq .001$ 
Program Design and Firm Success in the ATP

Figure 4. Estimated Increase in Patents per Year, by Type of Participation

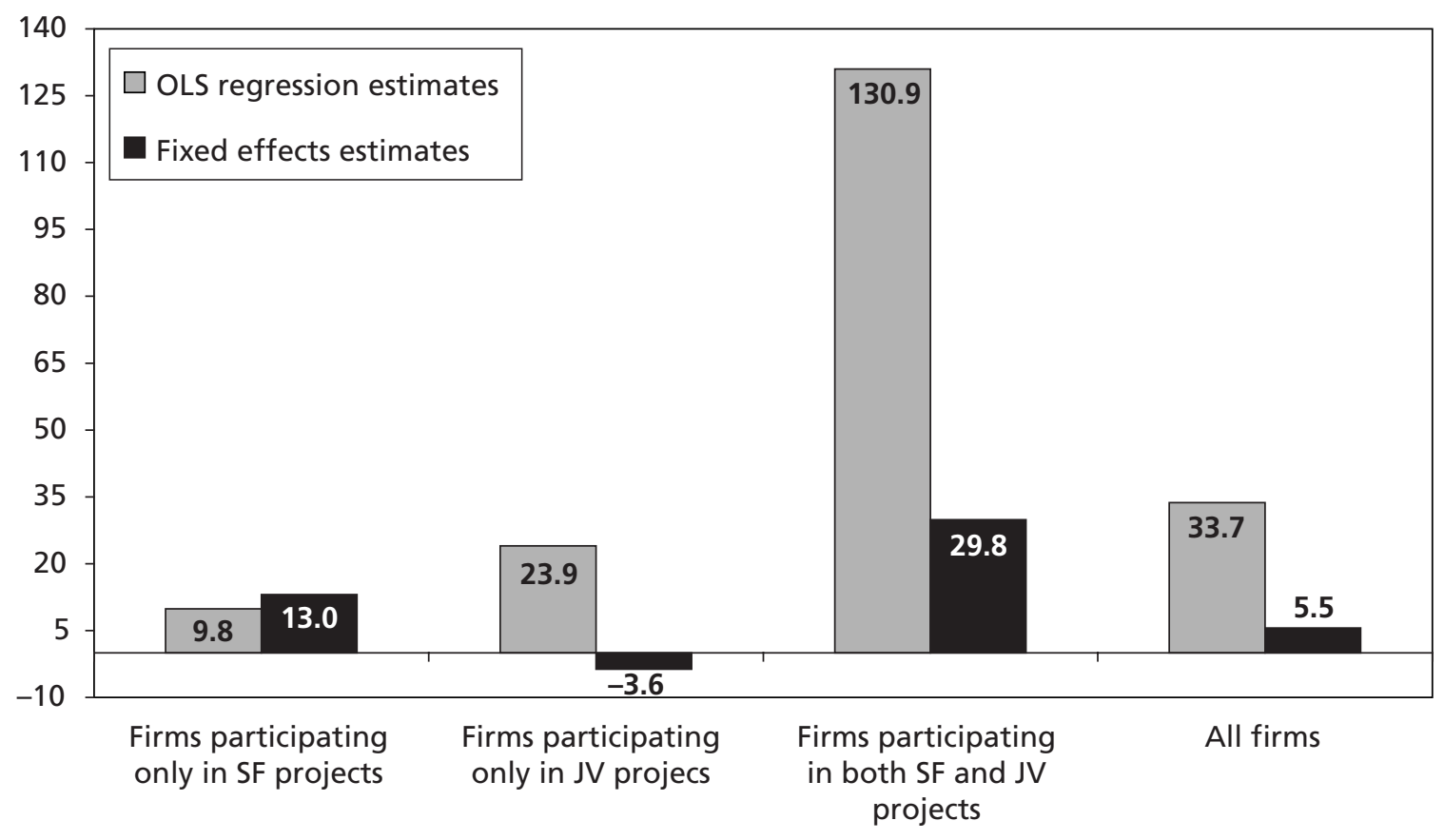

Figure 5. Estimated Increase in Patents per Year, by Type of University Role

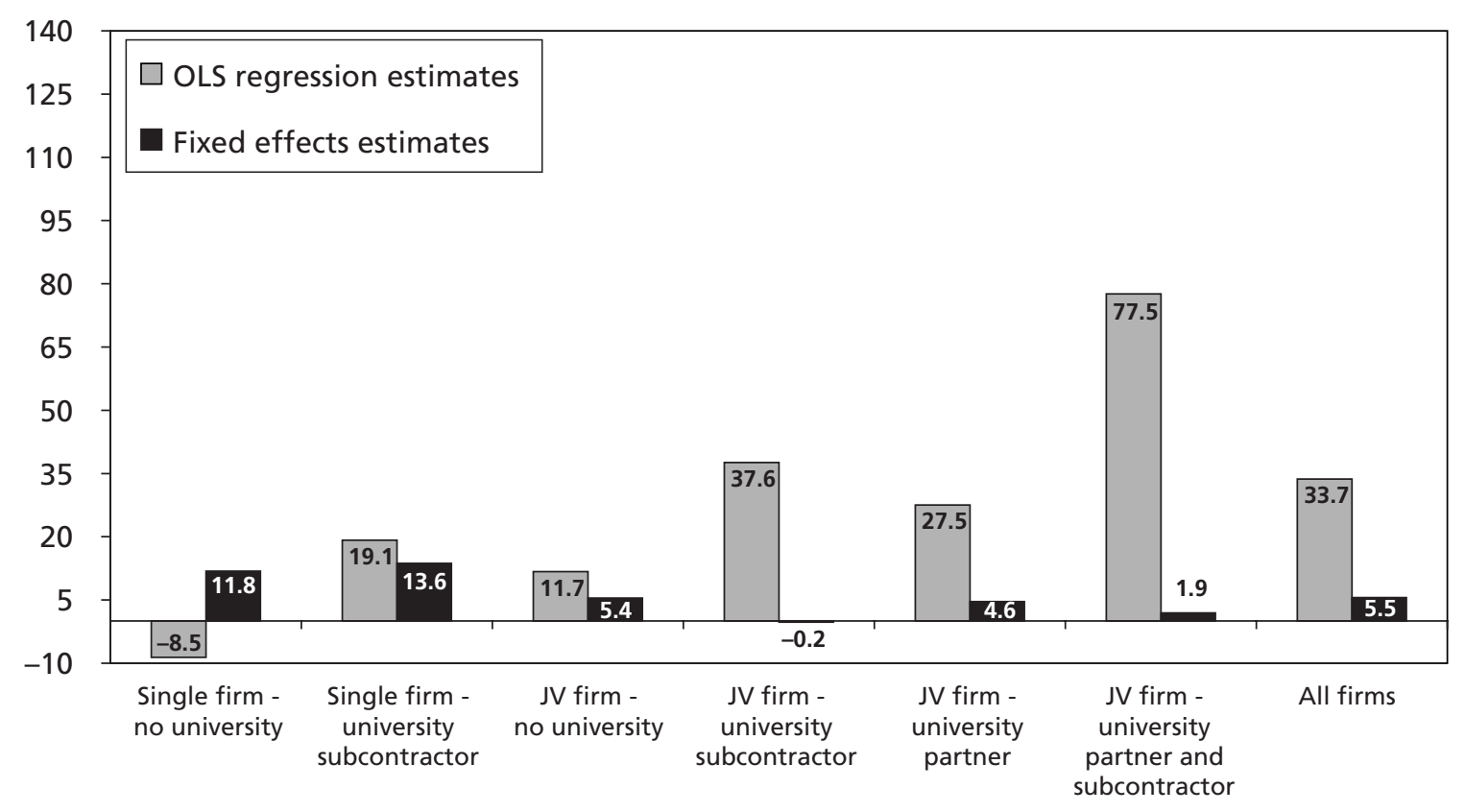


Table 6. Patenting by All Firms: Intensity of ATP Project ParticipationFixed Effects Regression

\begin{tabular}{lccc}
\hline Dependent variable & Patents, by date of application & (deflated; one year lag) \\
\hline Specification & 5.1 & 5.2 & 5.3 \\
Estimation & Fixed effects & Fixed effects & Fixed effects \\
Constant & $38.381^{* * *}$ & $37.869^{* * *}$ & $37.815^{* * *}$ \\
& $(1.087)$ & $(1.079)$ & $(1.081)$ \\
ATP participant & $-7.933^{* *}$ & $-26.099^{* * *}$ & $-26.423^{* * *}$ \\
& $(2.617)$ & $(4.924)$ & $(5.663)$ \\
Cumulative ATP award stock (\$000s) & $0.012^{* * *}$ & $0.033^{* * *}$ & $0.033^{* * *}$ \\
& $(0.002)$ & $(0.003)$ & $(0.004)$ \\
ATP JV participant & & $21.791^{* * *}$ & $26.030^{* * *}$ \\
& & $(5.693)$ & $(7.306)$ \\
Cumulative ATP JV award stock (\$000s) & & $-0.032^{* * *}$ & $-0.032^{* * *}$ \\
& & $(0.005)$ & $(0.005)$ \\
JV with university partner & & 0.552 \\
& & & $(5.366)$ \\
JV with university subcontractor & & & -7.500 \\
SF with university subcontractor & & & $(5.365)$ \\
& & $0.898^{* * *}$ & $(6.580$ \\
Adjusted R-squared & $0.896^{* * *}$ & $0.898^{* * *}$ \\
N & 2694 & 2694 \\
\hline
\end{tabular}

Significance levels: $* \mathrm{p} \leq .05, * * \mathrm{p} \leq .01, * * * \mathrm{p} \leq .001$ 
Program Design and Firm Success in the ATP

Table 7. Patenting by Public Firms: Intensity of ATP Project ParticipationOLS Regression

\begin{tabular}{|c|c|c|c|c|}
\hline \multirow{2}{*}{$\frac{\text { Dependent variable }}{\text { Specification }}$} & \multicolumn{4}{|c|}{ Patents, by date of application (deflated; one year lag) } \\
\hline & 6.1 & 6.2 & 6.3 & 6.4 \\
\hline Estimation & OLS & OLS & OLS & OLS \\
\hline Constant & $\begin{array}{c}-53.504^{* *} \\
(20.015)\end{array}$ & $\begin{array}{c}-47.167^{*} \\
(19.643)\end{array}$ & $\begin{array}{c}-46.005^{*} \\
(19.140)\end{array}$ & $\begin{array}{c}-46.186^{*} \\
(19.207)\end{array}$ \\
\hline Small & $\begin{array}{c}-14.990 \\
(13.098)\end{array}$ & $\begin{array}{c}-18.182 \\
(12.858)\end{array}$ & $\begin{array}{c}-18.858 \\
(12.562)\end{array}$ & $\begin{array}{c}-17.303 \\
(12.634)\end{array}$ \\
\hline Large & $\begin{array}{l}112.381 * * * \\
(12.656)\end{array}$ & $\begin{array}{l}108.875^{* * *} \\
(12.371)\end{array}$ & $\begin{array}{l}105.712^{* * *} \\
(12.064)\end{array}$ & $\begin{array}{l}105.019^{* * *} \\
(12.062)\end{array}$ \\
\hline Biotechnology & $\begin{array}{l}75.316^{* *} \\
(23.841)\end{array}$ & $\begin{array}{l}66.516^{* *} \\
(23.371)\end{array}$ & $\begin{array}{l}75.078^{* * *} \\
(22.961)\end{array}$ & $\begin{array}{l}74.947^{* * *} \\
(23.085)\end{array}$ \\
\hline Electronics & $\begin{array}{l}168.140 * * * \\
(23.512)\end{array}$ & $\begin{array}{l}147.106^{* * *} \\
(23.240)\end{array}$ & $\begin{array}{l}142.296 * * * \\
(22.655)\end{array}$ & $\begin{array}{l}147.340 * * * \\
(22.927)\end{array}$ \\
\hline Energy & $\begin{array}{c}35.455 \\
(29.801)\end{array}$ & $\begin{array}{c}23.647 \\
(29.182)\end{array}$ & $\begin{array}{c}19.729 \\
(28.653)\end{array}$ & $\begin{array}{c}22.630 \\
(28.717)\end{array}$ \\
\hline Information technology & $\begin{array}{l}71.224^{* * *} \\
(20.245)\end{array}$ & $\begin{array}{l}68.329 * * * \\
(19.851)\end{array}$ & $\begin{array}{l}65.698^{* * *} \\
(19.346)\end{array}$ & $\begin{array}{l}66.442^{* * *} \\
(19.625)\end{array}$ \\
\hline Manufacturing & $\begin{array}{l}-4.701 \\
(20.553)\end{array}$ & $\begin{array}{c}-3.904 \\
(20.089)\end{array}$ & $\begin{array}{c}-5.763 \\
(19.582)\end{array}$ & $\begin{array}{c}-5.985 \\
(19.669)\end{array}$ \\
\hline Materials & $\begin{array}{c}54.413^{*} \\
(21.919)\end{array}$ & $\begin{array}{c}48.480^{*} \\
(21.429)\end{array}$ & $\begin{array}{l}42.785^{*} \\
(20.892)\end{array}$ & $\begin{array}{c}42.536^{*} \\
(20.905)\end{array}$ \\
\hline Cumulative R\&D stock (\$millions) & $\begin{array}{l}0.023^{* * *} \\
(0.001)\end{array}$ & $\begin{array}{l}0.021^{* * *} \\
(0.001)\end{array}$ & $\begin{array}{l}0.021^{* * *} \\
(0.001)\end{array}$ & $\begin{array}{l}0.021^{\text {*** }} \\
(0.001)\end{array}$ \\
\hline ATP participant & & $\begin{array}{c}-28.738^{*} \\
(12.065)\end{array}$ & $\begin{array}{c}-133.849^{* * *} \\
(22.832)\end{array}$ & $\begin{array}{c}-152.559 \text { *** } \\
(25.402)\end{array}$ \\
\hline Cumulative ATP award stock (\$000s) & & $\begin{array}{l}0.039^{* * *} \\
(0.005)\end{array}$ & $\begin{array}{l}0.110^{* * *} \\
(0.011)\end{array}$ & $\begin{array}{l}0.095^{* * *} \\
(0.013)\end{array}$ \\
\hline ATP JV participant & & & $\begin{array}{l}127.730^{* * *} \\
(24.264)\end{array}$ & $\begin{array}{l}132.109^{* * *} \\
(29.901)\end{array}$ \\
\hline Cumulative ATP JV award stock (\$000s) & & & $\begin{array}{c}-0.106^{* * *} \\
(0.014)\end{array}$ & $\begin{array}{l}-0.093^{* * *} \\
(0.016)\end{array}$ \\
\hline$J V$ with university partner & & & & $\begin{array}{c}11.558 \\
(19.331)\end{array}$ \\
\hline JV with university subcontractor & & & & $\begin{array}{c}14.396 \\
(19.841)\end{array}$ \\
\hline SF with university subcontractor & & & & $\begin{array}{c}50.318 \\
(28.264)\end{array}$ \\
\hline Adjusted R-squared & $0.456^{* * *}$ & $0.481 * * *$ & $0.507^{* * *}$ & $0.508^{* * *}$ \\
\hline $\mathrm{N}$ & 1067 & 1067 & 1067 & 1067 \\
\hline
\end{tabular}

Significance levels: $* \mathrm{p} \leq .05, * \mathrm{p} \leq .01, * * \mathrm{p} \leq .001$ 
Table 8. Patenting by Public Firms: Intensity of ATP Project ParticipationFixed Effects Regression

\begin{tabular}{lccc}
\hline Dependent variable & Patents, by date of application (deflated; one year lag) \\
\hline Specification & 7.1 & 7.2 & 7.3 \\
Estimation & Fixed effects & Fixed effects & Fixed effects \\
Constant & $92.380^{* * *}$ & $85.931^{* * *}$ & $86.577^{* * *}$ \\
& $(4.411)$ & $(4.510)$ & $(4.588)$ \\
Cumulative R\&D stock (\$millions) & -0.004 & 0.000 & -0.001 \\
& $(0.002)$ & $(0.002)$ & $(0.002)$ \\
ATP participant & -10.445 & $-35.389^{* *}$ & -21.368 \\
& $(5.871)$ & $(11.792)$ & $(13.797)$ \\
Cumulative ATP award stock (\$000s) & $0.013^{* * *}$ & $0.044^{* * *}$ & $0.049^{* * *}$ \\
& $(0.003)$ & $(0.006)$ & $(0.007)$ \\
ATP JV participant & & $27.911^{*}$ & 13.507 \\
& & $(13.215)$ & $(17.088)$ \\
Cumulative ATP JV award stock (\$000s) & & $-0.048^{* * *}$ & $-0.053^{* * *}$ \\
& & $(0.009)$ & $(0.009)$ \\
JV with university partner & & & 20.598 \\
& & & $(11.551)$ \\
JV with university subcontractor & & & -12.424 \\
& & & $(11.280)$ \\
SF with university subcontractor & & $0.908^{* * *}$ & -29.199 \\
Adjusted R-squared & $0.905^{* * *}$ & 1067 & $0.9038^{* * *}$ \\
N & 1067 & 1067 \\
\hline
\end{tabular}

Significance levels: *p $\leq .05, * * \mathrm{p} \leq .01, * * \mathrm{p} \leq .001$

\section{Conclusions and Implications}

We find that patenting generally increases after ATP participation under a number of different program and participant variations. For firms in the sample, patenting increased on average by between 5 and 30 patents each year during the period of participation. These estimates are conservative since future effects from the ATP project participation are not included, even though they are implied in our regression models. The findings of this study also support the idea that joint ventures and university collaboration have a positive impact on firm patenting and innovation.

Positive effects on innovation for firms participating in ATP are significant and robust in the analyses we report in this paper. Our proxy measure of innovationfirm patents-suggests that the effect of the ATP project spreads beyond the 
Program Design and Firm Success in the ATP

project and has impact on the entire firm. We may interpret this result as evidence that ATP project participation supports firm-wide behavioral or organizational changes that foster an increased rate innovation. Alternatively, "internal spillovers" of knowledge or other benefits from one project to other projects may help explain the broad firm-wide effects of ATP participation.

This study considers the effect of program design-particularly project structure and university participation-on the innovation success of firm participants. The findings indicate that joint venture collaboration and university participation have a positive effect on innovation outcomes as measured by patents. These results are interpreted from a sociological perspective that emphasizes institution-building and social relationships as fundamental to the innovation process. From this perspective, ATP as a public-private partnership program fulfills a role in fostering institutions and social processes that facilitate innovation.

\section{References}

Advanced Technology Program (ATP). 1999. Proposal Preparation Kit. Washington, D.C.: National Institute for Standards and Technology.

Das, T.K., and Bing-Sheng Teng. 1998. "Between Trust and Control: Developing Confidence in Partner Cooperation in Alliances." Academy of Management Review 23(3):491-512.

Doz, Yves L. 1996. "The Evolution of Cooperation in Strategic Alliances: Initial Conditions or Learning Processes?” Strategic Management Journal 17:55-83.

Gould, Roger V. 1993. "Collective Action and Network Structure." American Sociological Review 58(2):182-196.

Granovetter, Mark. 1973. "The Strength of Weak Ties." American Journal of Sociology 78:1360-1380.

- 1985. "Economic Action and Social Structure: The Problem of Embeddedness." American Journal of Sociology 91:481-510.

Griliches, Zvi. 1990. "Patent Statistics as Economic Indicators: A Survey." Journal of Economic Literature 28:1661-1707. 
Hamel, Gary. 1991. “Competition for Competence and Inter-Partner Learning within International Strategic Alliances.” Strategic Management Journal 12:83-103.

Helper, Susan, John Paul MacDuffie, and Charles Sabel. 1998. “The Boundaries of the Firm as a Design Problem." Paper presented at the Make versus Buy: The New Boundaries of the Firm Conference, Columbia Law School, May.

Jaffe, Adam B. 1989. "Real Effects of Academic Research.” American Economic Review 79(5):957-970.

Jensen, Richard, and Marie Thursby. 2001. "Proofs and Prototypes for Sale: The Tale of University Licensing." American Economic Review 91:240-259.

Liebeskind, Julia Porter, Amalya Lumerman Oliver, Lynne G. Zucker, and Marilynn B. Brewer. 1996. "Social Networks, Learning, and Flexibility: Sourcing Scientific Knowledge in New Biotechnology Firms.” Organization Science 7(4):428-443.

Macaulay, Stewart. 1963. "Non-Contractual Relations in Business: A Preliminary Study." American Sociological Review 28(1):55-67.

Nelson, Richard R., and Sidney G. Winter. 1982. An Evolutionary Theory of Economic Change. Cambridge, MA: The Belknap Press.

Powell, Jeanne W., and Karen L. Lellock. 2000. Development, Commercialization, and Diffusion of Enabling Technologies: Progress Report. Washington, D.C. National Institute of Standards and Technology.

Thursby, Jerry G., and Marie C. Thursby. 2000. "Who is Selling the Ivory Tower? Sources of Growth in University Licensing." National Bureau of Economic Research Working Paper No. W7718, May.

Zucker, Lynne G. 1986. "Production of Trust: Institutional Sources of Economic Structure, 1840-1920.” In L.L. Cummings and Barry Staw, eds., Research in Organizational Behavior. Vol. 8. Greenwich, CN: JAI Press,

Zucker, Lynne G., and Michael R. Darby. 1996. "Star Scientists and Institutional Transformation: Patterns of Invention and Innovation in the Formation of the Biotechnology Industry." Proceedings of the National Academy of Sciences 93(23):12,709-12,716. 
- 1998. "Capturing Technological Opportunity via Japan’s Star Scientists: Evidence from Japanese Firms' Biotech Patents and Products.” National Bureau of Economic Research Working Paper No. 6360, January.

Zucker, Lynne G., Michael R. Darby, and Jeff Armstrong. 1998a. "Geographically Localized Knowledge: Spillovers or Markets?" Economic Inquiry 36(1):65-86.

Zucker, Lynne G., Michael R. Darby, and Marilynn B. Brewer. 1998b. "Intellectual Human Capital and the Birth of U.S. Biotechnology Enterprises.” American Economic Review 88(1):290-306.

Zucker, Lynne G., Michael R. Darby, Marilynn B. Brewer, and Yusheng Peng. 1996. "Collaboration Structure and Information Dilemmas in Biotechnology: Organizational Boundaries as Trust Production." In Roderick M. Kramer and Tom R. Tyler, eds., Trust in Organizations. Thousand Oaks, CA: Sage. 


\section{About the Advanced Technology Program}

The Advanced Technology Program (ATP) is a partnership between government and private industry to conduct high-risk research to develop enabling technologies that promise significant commercial payoffs and widespread benefits for the economy. The ATP provides a mechanism for industry to extend its technological reach and push the envelope beyond what it otherwise would attempt.

Promising future technologies are the domain of ATP:

- Enabling technologies that are essential to the development of future new and substantially improved projects, processes, and services across diverse application areas;

- Technologies for which there are challenging technical issues standing in the way of success;

- Technologies whose development often involves complex "systems" problems requiring a collaborative effort by multiple organizations;

- Technologies which will go undeveloped and/or proceed too slowly to be competitive in global markets without ATP.

The ATP funds technical research, but it does not fund product development-that is the domain of the company partners. The ATP is industry driven, and that keeps it grounded in real-world needs. For-profit companies conceive, propose, co-fund, and execute all of the projects cost-shared by ATP.

Smaller firms working on single-company projects pay a minimum of all the indirect costs associated with the project. Large, "Fortune 500" companies participating as a single company pay at least 60 percent of total project costs. Joint ventures pay at least half of total project costs. Single-company projects can last up to three years; joint ventures can last as long as five years. Companies of all sizes participate in ATP-funded projects. To date, more than half of ATP awards have gone to individual small businesses or to joint ventures led by a small business.

Each project has specific goals, funding allocations, and completion dates established at the outset. Projects are monitored and can be terminated for cause before completion. All projects are selected in rigorous, competitions, which use peer review to identify those that score highest against technical and economic criteria.

Contact ATP for more information:

- On the Internet: http://www.atp.nist.gov

- $\quad$ By e-mail: atp@nist.gov

- $\quad$ By phone: 1-800-ATP-FUND (1-800-287-3863)

- By writing: Advanced Technology Program, National Institute of Standards and Technology, 100 Bureau Drive, Mail Stop 4701, Gaithersburg, MD 20899-4701

\section{About the Authors}

\section{Michael R. Darby}

Michael R. Darby is the Warren C. Cordner Professor of Money and Financial Markets in the Anderson Graduate School of Management and in the Departments of Economics and Policy Studies at UCLA, and Director of the John M. Olin Center for Policy in the Anderson School. Darby has served in senior U.S. government positions, including Assistant Secretary of the Treasury for Economic Policy (1986-89), Under Secretary of Commerce for Economic Affairs (1989-92), and Administrator of the Economics and Statistics Administration (1990-92). He has served on editorial boards for American Economic Review, Contemporary Economic Policy, Contemporary Policy Issues, Journal of International Money and Finance, and International Reports.

\section{Lynne G. Zucker}

Lynne G. Zucker is Professor of Sociology and Policy Studies, Director of the Center for International Science, Technology, and Cultural Policy in the School of Public Policy and Social Research, and Director of the Organizational Research Program at the Institute for Social Science Research at UCLA. Zucker has served on editorial boards for Administrative Science Quarterly, American Journal of Sociology, American Sociological Review, Pacific Sociological Review, and Symbolic Interaction. She has also served on the National Science Foundation Young Presidential Scholar Award Panel and the National Science Foundation Sociology Panel, as Consulting Sociologist with the American Institute of Physics, and Economist with the Statistics of Income Division of the U.S. Internal Revenue Service.

\section{Andrew J. Wang}

Andrew J. Wang is an economist in the Economic Assessment Office, Advanced Technology Program (ATP), National Institute of Standards and Technology (NIST). He received his Ph.D. in Economics from Harvard University in 1997. His work has focused on the development, design, and analysis of special surveys and data analysis projects used to evaluate ATP. 